\title{
Sustainable Economic Growth in the European Union under COVID-19 Conditions
}

Ruta Baneliene

\begin{abstract}
All countries of the European Union (EU) have had their economies impacted by COVID-19 and should focus their efforts on managing the negative impacts on their GDP growth. Since EU countries vary considerably in many criteria, the same policy would not fit all EU countries. This paper analyzes how sustainable economic growth could be maintained in the long run while considering three criteria, including R\&D investment, gross value added per employee and country size by population; and which factors could have the highest impacts on economic growth in the recovery process according to supply and demand. Countries were examined according to the mentioned criteria by applying the panel least squares method. The major estimation outputs show the stronger effect of the supply side on economic growth, the higher role of human capital in small EU countries where R\&D investment exceeds 3\% of GDP, and the critical effect of exports on GDP growth in the large EU countries with the lowest R\&D investment. This segment depends the most on smooth exports of goods and service flows and could be the most vulnerable under COVID-19 conditions. Therefore, seeking to keep economic growth on track, EU countries should use different strategies and fiscal measures depending on the most vulnerable factors for their economic growth. In addition, this is the right time to revise values of economic growth, and governments should be more focused on the recovery of their economies on the sustainable development goals (SDGs) agenda.
\end{abstract}

KEY WORDS: $\quad$ GDP growth, European Union countries, R\&D investment, employment, exports.

JEL Classification: $\quad$ A10, C23, E17, F01, F39, F63, O39, O40.

VILNIUS TECH (Vilnius Gediminas Technical University), Vilnius, Lithuania

\section{Introduction}

All European Union (EU) countries and the United Kingdom (UK) have faced the impacts of the first COVID-19 wave on their economic growth. In total nominal values, quarterly GDP in 2020Q2 dropped by $€ 522$ billion compared to 2019Q2 (see Figure 1). Therefore, all EU countries should focus their efforts on solving the negative impacts on their GDP growth.

Analyzing economic growth throughout the pandemic situation worldwide shows that eliminating COVID-19 is the cheapest path toward economic recovery (Aghion et al., 2021). Elimination has proven

Correspondence concerning this article should be addressed to:

Ruta Baneliene VILNIUS TECH (Vilnius Gediminas Technical University), J. Basanaviciaus str. 28, 03224 Vilnius, Lithuania. E-mail: ruta.baneliene@ vilniustech.lt, phone: +370 61434831 . to be most effective method to reduce health and economic damage in the mid and long terms (Chetty et al., 2020; Dorn et al., 2020). Although it is easier to say than implement, every country should be focused on maintaining economic growth by applying fiscal and other measures, at least during the short-run period.

To evaluate economic growth, many authors have applied production functions with different variations. In 2021, Fukao and Makino conducted a survey to evaluate human capital and economic growth in Japan during 1885-2015. For their evaluation of real value added, they chose variables such as capital, land, labor and productivity (Fukao \& Makino, 2021). Hofman and Valderrama (2021) chose average annual hours of work per worker and average years of education as labor factors, gross fixed capital formation as 
a capital factor and total factor productivity (TFP) to evaluate GDP growth.

In 2021, Ogbeifun and Shobande used variables such as saving, the average rate of growth of the working age population, and the rate of human capital accumulation (the mean years of schooling) to model GDP per working age person and industry value added to the working age population. To solve the endogeneity problem, life expectancy at birth, the fertility rate, the inflation rate, trade openness (exports plus imports relative to GDP), and government consumption ratio variables were used as control variables.

In 2020, Chakroun et al. evaluated economic growth using the export upgrading indicator. As control variables, they chose the ratio of investment to GDP, the share of the population enrolled in secondary schooling, the openness rate measured as the share of imports and exports in GDP, and the foreign direct investment (FDI) inflows over GDP.

Furthermore, sustainable economic growth and sustainability in broad understanding cover a much wider spectrum of variables than traditional production functions, and they could be represented using environmental and social variables. In 2021, Gaya Herrington used World3 modeling scenarios (Meadows et al., 2005) conducted simulations using population, fertility and mortality, food per capita, industrial output per capita, services per capita, pollution, nonrenewable resources, human welfare and human ecological footprint data. She concluded that even when paired with unprecedented technological development and adoption, the business as usual scenario would inevitably lead to declines in industrial capital, agricultural output, and welfare levels within this century (Herrington, 2021).

The different perspectives on welfare are closely related to the positions taken on the question of whether continued economic growth is feasible and desirable. Whereas some argue that reductions in economic activity are a central element to mitigate environmental problems (degrowth), others emphasize the importance of decoupling economic activity from environmental impacts (Jacob et al., 2020).

\section{Figure 1}

Impacts of the First COVID-19 Wave on Economic Growth in European Union Countries (Quarterly GDP in Current Prices, billion €)

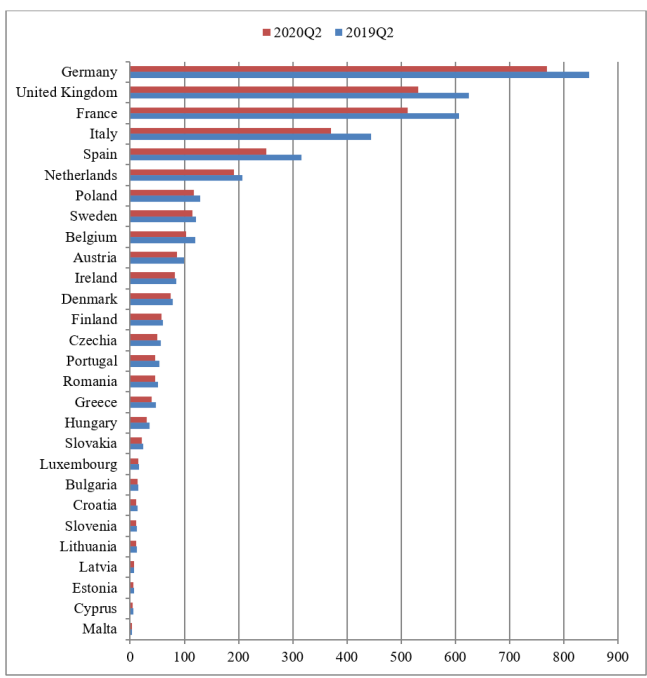

Source: Prepared by the author based on Eurostat data (2020d). 
Summarizing recent modeling methods for economic growth shows that many authors based their simulations on production functions, including labor, capital and technological perspectives. Expanded modeling using a production function includes environmental and social factors. However, considering pandemic conditions, our simulation is focused on the supply and demand sides of GDP and seeks to evaluate which side and factors are more important under COVID-19 and where the efforts of EU countries should be focused. In addition, attention should be given to different pulls of EU countries due to their wide ranges of population sizes, R\&D investment and differences in economic development measured as gross value added per employee. Investment in R\&D criteria is used only for segmentation countries in different pulls seeking to evaluate $R \& D$ relations to other factors that impact GDP growth.

The novelty of this research is that it considers both sides of GDP - supply and demand - and the major aim is to evaluate which side is most important under COVID-19 conditions in the European Union and in separate pulls of countries segmented by gross value added, R\&D investment and population size.

Hence, this research goal is to evaluate the impacts of supply and demand factors on GDP growth and identify the most vulnerable exogenous variables for the European Union and separate pulls of countries through R\&D investment, gross value added per employee and population size.

This research starts with the introduction section, which discloses the problems and novelty of sustainable economic growth. The second part of the paper presents a theoretical overview on the possible impacts of COVID-19 on sustainable economic growth supported by empirical evidence. The third part provides the empirical background of this research and is based on the identification of EU countries according to three criteria: R\&D investment as a \% of GDP, gross value added per employee and population size. The fourth part focuses on the model and data used to find sustainability approaches for economic growth from a long-run perspective, and the results section describes its outcomes. The conclusion and discussion section provides the major findings on long-term sustainable economic growth in EU countries under turbulent COVID-19 conditions.

\section{Theoretical Approach and Empirical Evidence}

Economic growth could be explained by three factors - labor, capital and technology (Cobb \& Douglas, 1928; Solow, 1956; Romer, 1994). Sustainable economic growth should include additional factors in the production function as a result of climate change (Nordhaus, 2019; Fremstad et al., 2019).

Population growth is only one factor that impacts GDP growth, but this factor cannot be the basis for the growth of GDP per capita (Solow, 1956; Mankiw et al., 1992).

Teixeira and Queirós (2016) highlighted the crucial effects of human capital, structural change processes in highly knowledge-intensive industries and their interaction on the economic growth of highly developed (OECD) countries; however, this impact could be negative in less developed countries due to the lack of industrial structures able to properly integrate highly educated individuals into the productive system. Economic growth is tied directly to productivity growth, which in turn depends on the discovery of new designs through R\&D. Individuals are the critical input into the discovery of new designs, and the growth rate of the economy depends crucially on the growth rate of the labor force (Jones, 1995). Higher human capital raises technological progress, which in turn raises the value of human capital (Galor \& Weil, 2000). High unemployment may have an adverse effect on growth because it reduces the pool of savings available for investment in physical or human capital or in knowledge-creating activities (Bean \& Pissarides, 1993).

However, the major engine of GDP growth in the long run is innovation and its six waves: five waves in the past - the industrial revolution, the steam age, the electricity age, mass production, and information and communication technologies (ICTs) - and the forthcoming sixth wave of innovation based on sustainability (Silva et al., 2016). The latest ICT innovation wave accelerated GDP growth in the 1960s using surfaced digital technology, in the 1970s using matured electronic networks, in the 1980s using hit personal computers, in the 1990s using the emergence of the World Wide Web, and in the 2000s using search engines. Currently, many more technological advantages could be used by businesses 
and the public sector with access to a huge amount of information on the Internet (Higgins, 2015), which would have a significant impact on economic growth. Despite the impact of ICTs on boosting economies, the forthcoming sustainability wave increases the importance by creating added value in a friendly manner for the environment, social protection, equality and other factors important for sustainable GDP development.

Despite all efforts, wise ideas and political will for sustainable economic growth, well-grounded GDP growth in the long run could be affected by unexpected factors in the short run such as the worldwide pandemic situation. COVID-19 has shocked the economy from both the supply and demand sides, and both aspects impact international trade. Despite being unaffected by the direct impacts on the service sector due to forced restrictions on retail, restaurants, beauty services, movie theatres, and other services, the manufacturing sector will probably experience the largest hit in the short run due to the following reason: (a) direct supply shocks caused by supply chain disruptions (Spash, 2020); and (b) demand disruptions due to recessions and precautionary delayed purchases by consumers and delayed investment by firms (Baldwin \& Tomiura, 2020).

Supply shocks will force companies to reduce or localize their supply chains when working under pandemic conditions and form alternative production or procurement plans to guard against a prolonged disruption, which will sacrifice efficiency and profit maximization for supply security and resilience (Schwab \& Malleret, 2020).

Regarding labor, decreased production is due to worker illnesses due to the pandemic situation. However, days off are the least important factor due to companies' ability to find ways to compensate for these days by providing overtime on days affected by worker illness. It could increase costs and might lead to some temporary inflation, but this pandemic impact will reduce GDP only in the short run by a few percentage points (Wren-Lewis, 2020).

Demand shock will depend on how consumers behave and consume social things that bring people together such as going to pubs, restaurants, and football matches and travel. Other service sectors that involve personal contact (beauty procedures, etc.) that could be easily postponed may also be hit. Therefore, the greatest impacts on GDP occur due to reduced social consumption (Wren-Lewis, 2020). Stopping cross-border travel would lead to major disruptions of economic activity (Meninno \& Wolff, 2020; Kitamura et al., 2020).

According to preliminary estimates of the economic impacts of COVID-19, GDP losses are expected due to shocks in the labor supply (IMF, 2020; Duan et al., 2020) via illness and mortality (Maliszewska et al., 2020; McKibbin \& Fernando, 2020; WTO, 2020; Eichenbaum et al., 2020), unemployment (International Labour Organization, 2020; McKibbin \& Fernando, 2020b), decreased consumption (McKibbin \& Fernando, 2020; Banco de Espana, 2020; Duan et al., 2020; Eichenbaum et al., 2020; WTO, 2020), financial market disruptions and tighter credit (IMF, 2020; McKibbin \& Fernando, 2020), decreased commodity and oil prices (IMF, 2020), increased trade costs (WTO, 2020) for all goods and services (Maliszewska et al., 2020), increased costs of doing business (McKibbin \& Fernando, 2020), decreased tourism (WTO, 2020; Breisinger et al., 2020) implemented with increase in cost (Maliszewska et al., 2020), and decreased manufacturing (WTO, 2020).

All mentioned scientific insights and first estimation results are clearly proven by the World Bank, OECD and Eurostat statistical data. According to the World Bank (2020) baseline forecast, a 5.2\% contraction in global GDP was expected in 2020. However, in 2021, global economic growth will recover and reach $4.2 \%$. The decline of GDP in the euro area under the same scenario was $9.1 \%$ and was the deepest drop among advanced economies in 2020. Nevertheless, the recovery of the euro area will be much faster than that of other advanced economies and will reach $4.5 \%$ real GDP growth in 2021. The current global recession is projected to last only one year with a return to GDP growth in 2021. The first wave of COVID-19 has had a negative impact on the retail sales volume, trade volume, unemployment rate and oil consumption, which were outcomes of decreased real GDP and GDP per capita (World Bank, 2020).

According to the OECD economic outlook (2020), global real GDP was expected to shrink by $-4.2 \%$ in 
2020 and recover in 2021 to $4.2 \%$ growth. The euro area faces the highest GDP decrease among advanced economies and was expected to decrease by $7.5 \%$ in 2020 with moderate $3.6 \%$ recovery in 2021 . One of the largest COVID-19 impacts was a $10.3 \%$ sharp decrease in world real trade with a $3.9 \%$ recovery in 2021.

However, all forecast scenarios are based on assumptions and vary significantly. For example, McKibbin \& Fernando (2020a, b) estimated the global macroeconomic impacts of COVID-19 according to seven scenarios in which the German economy shrinks from $-0.2 \%$ to $-8.7 \%$ in 2020 , French GDP decreases from $-0.2 \%$ to $-8.0 \%$ in 2020 , and Italian GDP decreases from $-0.2 \%$ to $-8.3 \%$ in 2020 .

Analyzing the impacts of COVID-19 in the European Union, decreased production could be noticed: in November 2020, compared with November 2019 , the production of energy fell by $5.3 \%$ and that of nondurable consumer goods by $2.6 \%$; however, the production of intermediate goods increased by $1.7 \%$, that of durable consumer goods increased by $1.4 \%$ and that of capital goods increased by $0.4 \%$ (Eurostat, 2021c). The first estimate for extra-EU exports of goods in November 2020 was $€ 176.6$ billion, down by $1.5 \%$ compared with November 2019 (€179.3 bn). Imports from the rest of the world were $€ 151.3$ bn, down by $6.2 \%$ compared with November 2019 ( $€ 161.3 \mathrm{bn}$ ). In the first eleven months of 2020, China was the main trade partner for the EU. This result was due to an increase in imports $(+4.3 \%)$ and exports $(+1.1 \%)$. Furthermore, trade with the United States recorded a significant drop in both imports $(-13.0 \%)$ and exports (-9.3\%) (Eurostat, 2021b).

Additionally, it should be noted that COVID-19 has resulted in an unprecedented increase in the bank deposits of nonfinancial corporations and households. This could be explained by a decrease in social (international travel, restaurants, cultural events, etc.) and other service consumption due to the restrictions introduced by governments to combat the conditions of the pandemic, thus increasing savings and bank deposits. In addition, high uncertainty of the future after the pandemic raised precautionary savings, discouraging investment and purchases of durable goods (OECD, 2020).

According to Eurostat (2021a) data, the household saving rates of the EU-27 and euro area (EA-19) had their highest annual increases (2020Q2 vs 2019Q2, nonseasonally adjusted data) since the beginning of the time series at +10.8 and +10.6 percentage points (pp), respectively. The main reason is the pronounced annual decrease in household final consumption expenditures $(-17.3 \%$ in the EU-27 and $-15.3 \%$ in the euro area).

Despite the many threats and restrictions that have had deep but short-run impacts on economic growth worldwide, pandemic situations could be a good opportunity to break consumerism and return to economic growth based on the values of the sustainable development goals (SDGs) agenda.

The bulk of consumers stimulate economic growth by searching for personal gratification in nicotine, caffeine, drugs, chocolate, food, alcohol, etc. The more goods they purchase, the more energy and technology that are needed to create these goods. Economic growth generates more economic growth. After this processing, the system produces waste and begins again (Higgins, 2015). Therefore, economic growth as a phenomenon has a dark side that exhausts our planet. The pandemic situation could help provide a short break to stop and examine the incentives of economic growth.

Despite good intentions, the negative effects of the pandemic situation on achieving the SDGs for 2030 is increased poverty levels, unemployment, and health risks and huge uncertainty regarding the effects on the environmental aspects of the global goals (Cruz, Almeida, Blom-El Nayal, 2020).

According to United Nations (2020) scenarios, in the wake of the pandemic, there are two possible paths ahead for the world: (a) pessimistic scenario a continuation of the pre-COVID-19 development path with progress further hindered by the pandemic, which means that sustainable development will be most certainly out of reach; and (b) optimistic scenario - countries will be able to contain the pandemic quickly and return to robust economic growth that would result in higher government revenues and greater capacity to invest in social protection. The post-COVID-19 optimistic scenario may follow a three-pronged strategy for building better social protection systems: social protection for all by 2030 and concerted efforts by countries to 
shockproof their social protection systems and adapt them to the digital economy (UN, 2020).

However, the worst economic outcome from COVID-19 could be a deep recession during which there are insufficient numbers of workers available to restore economic activity to its previous level. To prevent this situation, fiscal measures such as payments, subsidies, and loan guarantees should be introduced that could prevent the translation of short-term disruptions to long-run disruptions (Gans, 2020).

\section{Empirical Background}

The European Union includes countries that are very different countries in their population size, economic prosperity and attitudes toward R\&D, which is one of the most important factors for long-term sustainable economic growth. According to Eurostat data, sixteen countries (including the United Kingdom (UK) in this analysis as a former EU country) exceeded $€ 10000$ gross value added per employee in 2020Q2 under COVID-19 conditions; the other twelve countries were below this line. Analyzing countries by their R\&D investment shows that only four EU countries, Austria, Denmark, Germany and Sweden, have reached and slightly exceeded the line of R\&D activities comprising 3\% of GDP investment as was one of the EU major goals. All mentioned countries are high gross value added economies. Regarding the EU countries below the high value added criterion, only two - Czechia and Hungary - are on the way to reach the strategic R\&D investment goal, and none of the countries with lower gross value added (GVA) has had the intention to exceed this goal (see Table 1). The $\mathrm{R} \& \mathrm{D}$ expenditures criterion in this research is used only to segment EU countries, but this step provides evidence that long-run economic prosperity depends on R\&D investment.

In addition, the EU covers countries that significantly vary in population size. Less than half of the EU countries are large countries with populations above 10 million: Belgium, Czechia, France, Germany,

\section{Table 1}

EU Member States and the UK by R\&D Expenditures, Gross Value Added and Population

\begin{tabular}{|c|c|c|c|}
\hline & $\begin{array}{l}\text { R\&D expenditures } \\
\quad<=1.5 \% \text { GDP }\end{array}$ & $\begin{array}{c}1.5 \% \text { GDP }<\text { R\&D expenditures } \\
<=3.0 \% \text { GDP }\end{array}$ & $\begin{array}{c}\text { R\&D expenditures } \\
>3.0 \% \text { GDP }\end{array}$ \\
\hline GVA per employee $>€ 10000^{*}$ & $\begin{array}{c}\text { Ireland, Spain, Italy, } \\
\text { Cyprus, Luxembourg, } \\
\text { Malta }\end{array}$ & $\begin{array}{c}\text { Belgium, France, Netherlands, } \\
\text { Slovenia, Finland, United Kingdom }\end{array}$ & $\begin{array}{l}\text { Austria, Denmark, } \\
\text { Germany, Sweden }\end{array}$ \\
\hline GVA per employee $<=€ 10000$ & $\begin{array}{l}\text { Bulgaria, Estonia, } \\
\text { Greece, Croatia, Latvia, } \\
\text { Lithuania, Poland, } \\
\text { Portugal, Romania, } \\
\text { Slovakia }\end{array}$ & Czechia, Hungary & - \\
\hline Population $>10$ million & $\begin{array}{l}\text { Greece, Spain, Italy, } \\
\text { Poland, Portugal, Ro- } \\
\text { mania }\end{array}$ & $\begin{array}{l}\text { Belgium, Czechia, France, } \\
\text { Netherlands, United Kingdom }\end{array}$ & Germany, Sweden \\
\hline Population $<=10$ million & $\begin{array}{c}\text { Bulgaria, Estonia, } \\
\text { Ireland, Croatia, Cyprus, } \\
\text { Latvia, Lithuania, } \\
\text { Luxembourg, Malta, } \\
\text { Slovakia }\end{array}$ & Hungary, Slovenia, Finland & Austria, Denmark \\
\hline
\end{tabular}


Greece, Italy, the Netherlands, Poland, Portugal, Romania, Spain and Sweden. In this research, the United Kingdom is also included in this group. Other EU countries are classified as small countries regarding population.

Consequently, the EU is very complex regarding countries' size and economic prosperity and should be analyzed not only as a whole union but also by different segments based on R\&D, gross value added and population size.

Considering the major goal of this research - to evaluate the supply and demand factors that impact GDP growth and identify the most vulnerable exogenous variables for the European Union and separate pools of countries through R\&D investment, gross value added per employee and population size we do not propose a hypothesis related to supply and demand. However, we will include indicators such as gross value added and final consumption expenditures, which represent the supply and demand sides of GDP, in our model; and the estimated output will allow us to make related insights. In addition, based on theoretical insights and empirical evidence, the labor factor should be one of the most important factors for long-run economic growth. Therefore, employment and unemployment variables are included in our model. Additionally, under COVID-19 conditions, it would be reasonable to evaluate one of countries' openness factors - exports - and its impact on GDP growth. This factor has been chosen due to its possible relation with R\&D; and to evaluate whether such a relation exists, especially under COVID-19 conditions and the possible vulnerability of small EU countries, which could be called small open economy countries.

Hypotheses:

Hp1: Human resources (employment and unemployment) have a higher impact on sustainable economic growth in EU countries with higher R\&D investment (above 3\% of GDP).

Hp2: Exports have a higher impact on sustainable economic growth in small EU countries and depends on their R\&D investment.

Hence, the model is based on how supply and demand affect GDP and is focused on the evaluation of GDP growth factors for the EU and its separate pools of countries segmented by three criteria: R\&D investment, gross value added and population size.

\section{Methodology: Model and Data}

The health crisis has already transformed into an economic and labor market crisis impacting not only sup $\neg$ ply (the production of goods and services) but also demand (consumption and investment) (Khan et al., 2021).

The major idea of our model is based on the differences of the EU countries by population size and economic prosperity and includes independent supply and demand variables (see Figure 2) such as gross value added, which represents the supply side of GDP (comprised $89.3 \%$ of the European Union's GDP in 2019); final consumption expenditures, which represent the demand side of GDP (comprised 53.8\% of the European Union's GDP in 2019; calculation based on Eurostat data, 2020c, d, e); employment and unemployment, as a labor force factors, which represent both sides of GDP, supply through production and demand through consumption; and exports to investigate their impacts on sustainable economic growth. Capital, taxation, government purchases and imports are not included in the model.

The main equation of our model is as follows:

$G D P=c+G V A+F C E+E M+U N+E X+\varepsilon$

where GDP is gross domestic product at market prices in million euros, GVA is the gross value added at market prices in million euros, FCE - final consumption expenditures in million euros, $E M$ - employed persons in thousands, $U N$ - unemployed persons in thousands, and $E X$ - exports of goods and services in million euros.

Eurostat quarterly data for the period 2004Q1-2020Q2 (Eurostat, 2020a, b, c, d, e, i) were used for estimation. The starting point of data - the first quarter of 2004 was chosen due to the expansion of the EU in 2004. In 2004, ten countries joined the union, including the Baltic countries - Estonia, Latvia and Lithuania; Hungary; Poland; Czechia; Slovakia; Slovenia; and two islands Malta and Cyprus. For major estimation, 1814 observations were used, and the panel least squares method was applied. The same modeling method was used for other estimations with few exemptions. Cross-section weights were added due to working with nominal values and including large and small countries by population size in the same pool of countries for estimation. 


\section{Figure 1}

Impacts of the First COVID-19 Wave on Economic Growth in European Union Countries (Quarterly GDP in Current Prices, billion €)

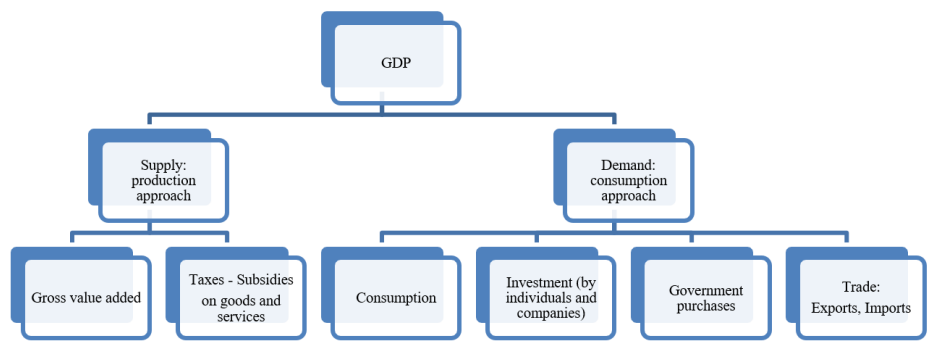

Source: Prepared by the author based on Eurostat \& European Commission, 2008; Mankiw, 2019.

\section{Results}

The major estimation using equation (1) for the entire EU shows that the highest impacts on sustainable economic growth come from two factors - growth in gross value added and decreased unemployment (see equation (2)).

$G D P=526.87+1.03 G V A+0.09 F C E+0.04 E M$

$-0.84 U N+0.02 E X+\varepsilon$

$\mathrm{R}$-squared $\left(\mathrm{R}^{2}\right)=0.9999$, adjusted R-squared $\left(\overline{\mathrm{R}}^{2}\right)=$ 0.9999, D-W $=1.1044, \mathrm{p}<0.01$, and EM coefficient $\mathrm{p}<0.05$.

Other estimations separating countries in different segments by R\&D expenditures, gross value added per employee and population size show tendencies that the major economic prosperity factors of well-developed countries with GVA per employee exceeding $€ 10000$ per quarter are the creation of gross value added (coefficients 0.85-1.08) and the labor factors - employment (coefficients
$0.25,-0.94$, and 1.26) and unemployment (coefficients -1.23 and 0.68 ). The impact of employment depends on R\&D investment: EU countries with higher R\&D investment have higher impacts of human resources on their GDP growth (see Table 2 , equations (3) and (5)), if no imbalances rise in the labor market (as shown in the results of equation (4)). In equation (5), the unemployment factor was irrelevant and excluded from the estimation, although its importance was noticed in separate estimations when countries were grouped by their population size (see Table 2, equations (10) and (13)). For large countries such as Germany and Sweden with populations greater than 10 million and R\&D investment exceeding 3\% of GDP, the major factors for sustainable economic growth are gross value added (coefficient 1.10) and unemployment (coefficient -2.43), which has a huge impact on economic growth. Unemployment decreasing by 1 thousand persons could increase quarterly GDP by $€ 2.43$ million. For small countries such as 
Austria and Denmark with populations below 10 million and R\&D investment exceeding $3 \%$ of GDP, three factors - gross value added (coefficient 0.94) and the labor factors of unemployment (coefficient -6.49) and employment (coefficient -0.99) - have critical effects on economic growth. Decreased unemployment has a 2.7 times higher impact for small countries compared to large countries under the same high R\&D investment and high gross value added conditions (see Tables 1 and 2, equations (10) and (13)).

However, unexpected outcomes are faced in small EU countries where estimations show imbalances in the labor market and the sensitive impacts on sustainable economic growth (see Table 2, equations (11), (12) and (13)).

For example, in small EU countries where R\&D investment is equal to or lower than $1.5 \%$ of GDP, increased employment has a slight but negative impact on economic growth (coefficient -0.23), but decreased unemployment has a positive impact on economic growth (coefficient -0.83). In small EU countries - Hungary, Slovenia, and Finland where investment in $\mathrm{R} \& \mathrm{D}$ is above $1.5 \%$ of GDP but below or equal to $3 \%$ of GDP, an unexpected result regarding unemployment has been obtained, and an increase in unemployment has a positive impact on GDP growth (coefficient 2.11). These results could be explained by a more precise investigation of the labor market and shadow economy structures of the mentioned countries, but this output is one of the limitations of this research.

According to the International Labor Organization (2021), the labor force is the sum of the numbers of employed and unemployed persons. Analyzing the estimation results through this perspective and the segmentation criteria of gross value added and population shows that the labor factor has clear tendencies in only one of four segments where gross value added per employee is less than or equal to $€ 10000$. The estimation results for the mentioned segment show that the labor factor is more important for the EU countries where $R \& D$ investment is higher $(1.5 \% \mathrm{GDP}<\mathrm{R} \& \mathrm{D}$ expenditures $<=3.0 \%$ GDP) and accumulated coefficient is 1.53 (0.38 EM, - $1.15 \mathrm{UN}$ - decreased unemployment has a positive impact on GDP growth, and the calculation of the accumulated labor factor coefficient includes a ' + ' sign), which has nearly a 3 times higher impact on GDP growth compared to the $0.54(-0.54 \mathrm{UN})$ coefficient of the EU countries where R\&D investment is equal or lower than $1.5 \%$ of GDP (see Table 2, equations (6) and (7)).

In general, the estimation results show the higher role of human capital in small EU countries where R\&D investment exceeds 3\% of GDP and has a higher impact on their sustainable economic growth (accumulated coefficient of the labor factor is $5.50(-0.99 E M,-6.49 \mathrm{UN})$ ) compared to large EU countries under the same conditions (accumulated coefficient of the labor factor is 3.06 (0.63 EM, -2.43 $U N$ ) (see Table 2, equations (10) and (13)).

Therefore, the estimation results for small EU countries proved the hypothesis that the labor factor has a higher impact on GDP growth in countries that have a proper focus on R\&D investment (exceeding $3 \%$ of GDP) as a major engine of economic growth (the highest accumulated labor factor coefficient (5.5) among the six simulation results by the population and R\&D investment segmentation criteria; also among three simulation results by the $\mathrm{R} \& \mathrm{D}$ segmentation criterion in the small countries segment). However, this hypothesis was not supported for large EU countries. In this segment, the highest effect of the human factor is in the pool of countries in which $\mathrm{R} \& \mathrm{D}$ investment is at the lowest level - below or equal to $1.5 \%$ of GDP.

Analyzing the effects of exports on economic growth, the estimations rejected the hypothesis that this factor has a higher impact on economic growth in small open economies but supported the part of hypothesis for R\&D investment: the exports of small EU countries with higher R\&D investment have a higher impact on economic growth (coefficients of $0.01,0.02$ and 0.6 , respectively) (see Table 2 , equations (11), (12) and (13)). Although the highest impact of exports on GDP growth (coefficient 0.40 ) is for the pool of large countries with the lowest R\&D investment (see Table 2, equation (8)), this segment of countries (Greece, Spain, Italy, Poland, Portugal, and Romania) is the most dependent on smooth exports of goods and service flows and could be the most vulnerable under COVID-19 conditions. 
Table 2

EU Member States and the UK by R\&D Expenditures, Gross Value Added and Population

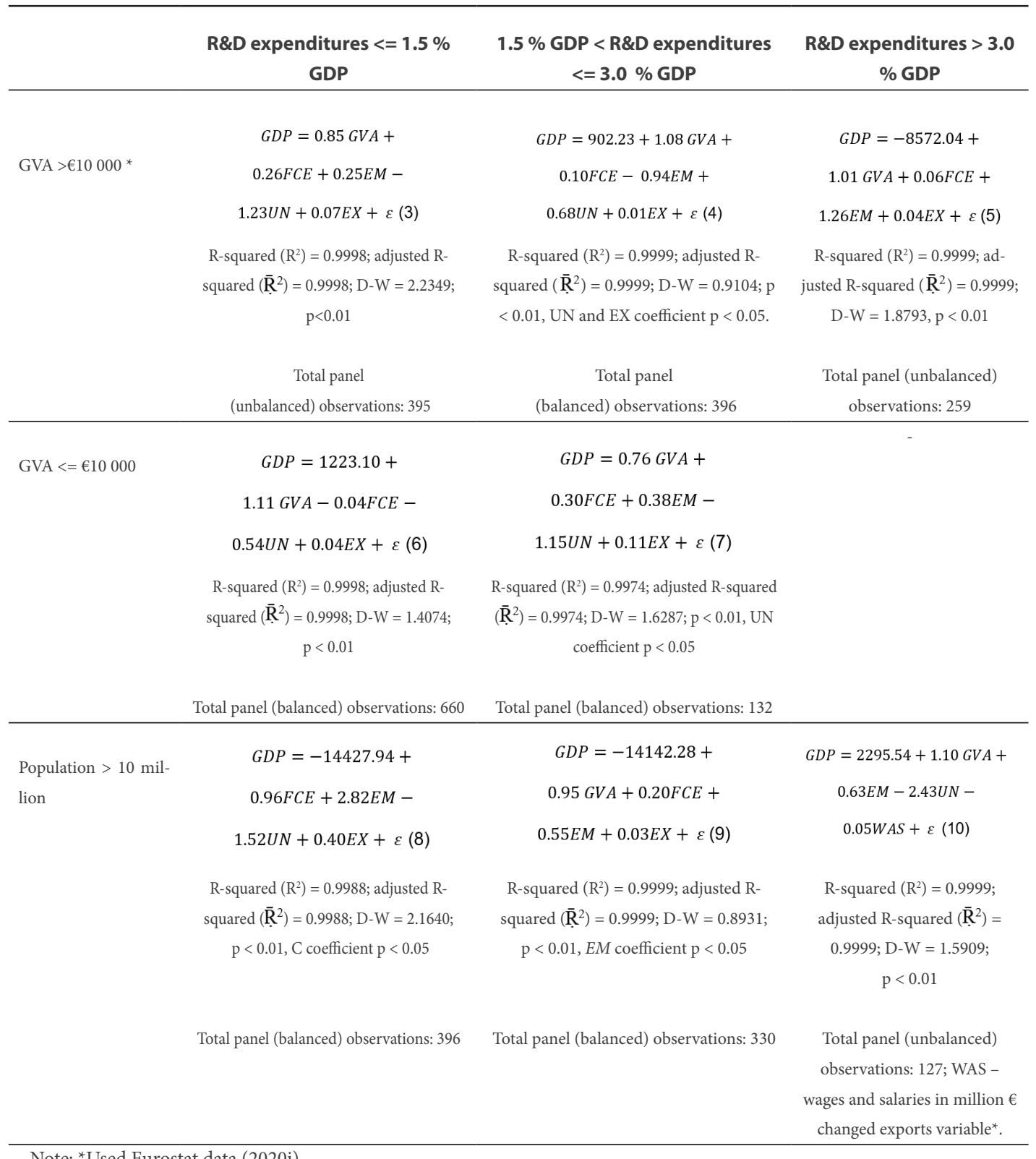

Note: ${ }^{\star}$ Used Eurostat data $(2020 \mathrm{j})$. 
Table 2

EU Member States and the UK by R\&D Expenditures, Gross Value Added and Population (Contiuned)

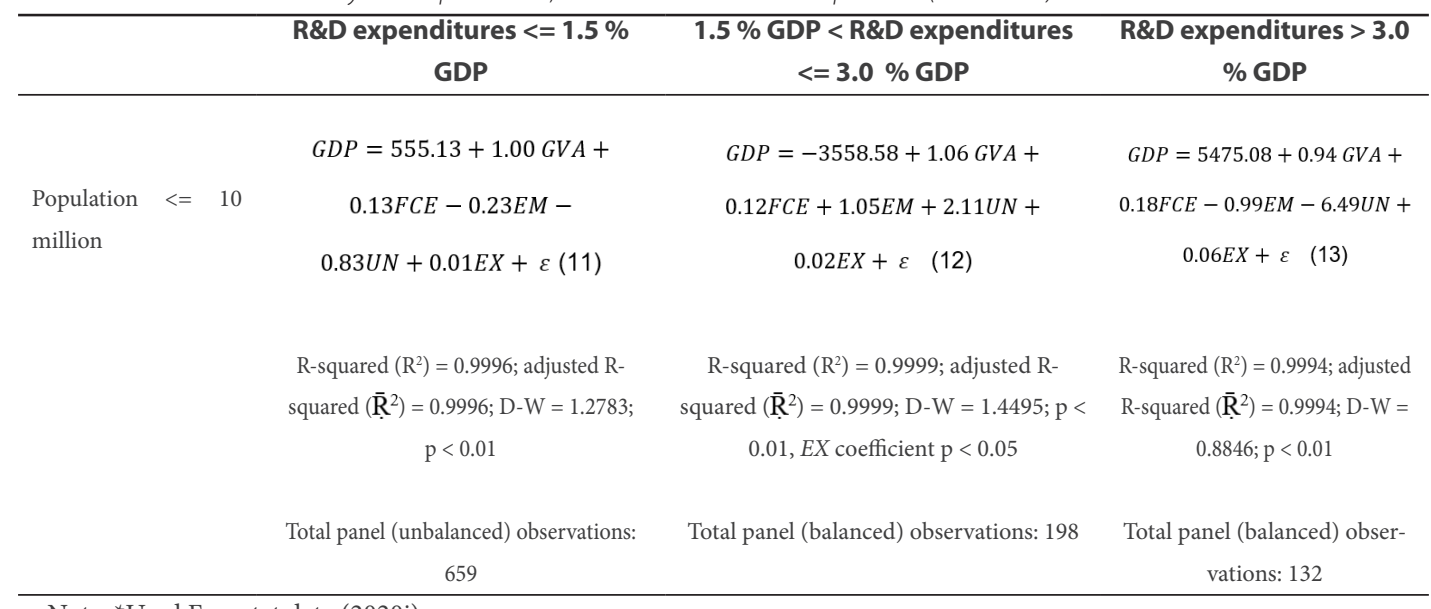

Note: ${ }^{\star}$ Used Eurostat data $(2020 j)$.

\section{Conclusions and Discussion}

All countries of the European Union have faced the impacts of the first COVID-19 wave on their economies and should focus their efforts on solving the issues related to the negative impacts on their GDP growth.

The major estimation for the entire EU shows that the highest impacts on sustainable economic growth come from two factors - growth in gross value added and shrink in unemployment. Additionally, the estimation results show the higher effect of human capital in small EU countries where R\&D investment exceeds 3\% of GDP and has a higher impact on their sustainable economic growth (accumulated coefficient of the labor factor is 5.50) compared to large EU countries under the same conditions (accumulated coefficient of the labor factor is 3.06). The estimation results for small EU countries proved the hypothesis that the labor factor has a higher impact on GDP growth in countries that have proper focus on $\mathrm{R} \& \mathrm{D}$ investment (exceed 3\% of GDP) as a major engine of economic growth but rejected this hypothesis for large EU countries. In this segment, the highest effect of the human factor is in the pool of countries where R\&D investment is at the lowest level - below or equal to $1.5 \%$ of GDP.
When analyzing the role of exports in economic growth, the estimations rejected the hypothesis that this factor has a higher impact on economic growth in small open economies but proved the part of this hypothesis in relation to R\&D investment: the exports of small countries with higher R\&D investment have a higher impact on economic growth. Although the highest impact of exports on GDP growth was in the pool of large countries with the lowest R\&D investment - Greece, Spain, Italy, Poland, Portugal, and Romania - this segment is most dependent on smooth exports of goods and service flows and could be the most vulnerable under COVID-19 conditions.

Therefore, when seeking to keep their economic growth on track, EU countries should use different strategies and fiscal measures depending on the most vulnerable factors for their economic growth. In addition, this is the right time to revise the values of economic growth, and governments should be more focused on the recovery of their economies on the SDGs agenda.

The theoretical implication of this research is based on evaluating supply and demand side approaches in one model seeking to investigate which factor could be more important for policymakers, especially during unexpected situations such as $\mathrm{CO}$ - 
VID-19. The practical added value of this research is the identification of the major factors that have higher impacts on economic growth in separate segments of EU countries. This identification could allow the application of appropriate measures (fiscal and others) with a clear focus on the most important areas of economic growth, particularly in the pool of countries (or country) seeking to avoid the worst possible situation under COVID-19 conditions - economic recession in the mid and long run.

The major limitation of this research is the limited scope of the modeling data. Including additional factors in the major equation (investment, savings, taxation, imports, climate change and others) could slightly change the estimation results.

Therefore, future work could be focused on evaluating a wider scope of indicators from the supply side and the demand side to better understand country vulnerabilities during unexpected situations that impact economic growth in the short, mid and long runs.

\section{Acknowledgment}

Funding: This research did not receive any specific grant from funding agencies in the public, commercial, or not-for-profit sectors.

\section{References}

Aghion, P., Artus, P., Oliu-Barton, M., \& Pradelski, B. (2021). Aiming for zero Covid-19 to ensure economic growth. Research-based policy analysis and commentary from leading economists. https:// voxeu.org/article/aiming-zero-covid-19-ensureeconomic-growth

Baldwin, R., \& Tomiura, E. (2020). Thinking ahead about the trade impact of COVID-19. In R. Baldwin, \& B. Weder di Mauro (Eds.) Economics in the time of COVID-19 (pp. 59-71). CEPR Press.

Banco de Espana. (2020). Reference macroeconomic scenarios for the Spanish economy after COVID-19. Economic bulletin 2. Banco de Espana.

Bean, C., \& Pissarides, C. (1993). Unemployment, consumption and growth. European economic review, 37, 837-859. https://doi.org/10.1016/00142921(93)90093-P

Breisinger, C., Abdelatif, A., Raouf, M., \& Wiebelt, M. (2020). COVID-19 and the Egyptian economy: Estimating the impacts of expected reductions in tourism, Suez Canal revenues, and remittances (Vol. 4).
Intl Food Policy Res Inst.

Chakroun, M., Chrid, N., \& Saafi, S. (2020). Does export upgrading really matter to economic growth? Evidence from panel data for high-, middle- and low-income countries. International journal of finance and economics, research article, 1-26. https://doi.org/10.1002/ijfe.2082

Chetty, R., Friedman, J. N., Hendren, N., \& Stepner, M. (2020). The economic impacts of COVID-19: evidence from a new public database built using private sector data. NBER, working paper 27431.

Cobb, C. W., \& Douglas, P. H. (1928). A theory of production. The American Economic Review, 18(1), 139-165.

Cruz, N. M., Almeida, F. P., \& Blom-El Nayal, M. (2020). The impact of COVID-19 on the sustainable development agenda: A business opportunity to reframe success. Research note. Católica-Lisbon Centre for Responsible Business \& Leadership. https://www.clsbe.lisboa.ucp.pt/ research-note-the-impact-of-covid-19-on-thesustainable-development-agenda-a-business-opportunity-to-reframe-the-future-

Dorn, F., Khailaie, S., Stoeckli, M., Binder, S. C., Lange, B., Lautenbacher, S., Peichl, A., Vanella, A., Wollmershäuser, T., Fuest, C., \& Meyer-Hermann, M. (2020). The common interests of health protection and the economy: Evidence from scenario calculations of COVID-19 containment policies. medRxiv. https://doi.org/10.1101/2020.08.14.201 75224

Duan, H., Bao, Q., Tian, K., Wang, S., Yang, C., \& Cai, Z. (2021). The hit of the novel coronavirus outbreak to China's economy. China Economic Review, 67, 101606. https://doi.org/10.1016/j. chieco.2021.101606

Eichenbaum, M. S., Rebelo, S., \& Trabandt, M. (2021). The macroeconomics of epidemics. The Review of Financial Studies, 34(11), 5149-5187. https://doi. org/10.1093/rfs/hhab040

Eurostat. (2020a). Employed persons. Retrieved on 21.11.2020 from: https://ec.europa.eu/eurostat/ data/database

Eurostat. (2020b). Exports of goods and services. Retrieved on 21.11.2020 from: https://ec.europa.eu/ eurostat/data/database

Eurostat. (2020c). Final consumption expenditure. Retrieved on 21.11.2020 from: https://ec.europa.eu/ eurostat/data/database

Eurostat. (2020d). Gross domestic product at market prices. Retrieved on 21.11.2020 from: https:// ec.europa.eu/eurostat/data/database 
Eurostat. (2020e). Gross value added. Retrieved on 21.11.2020 from: https://ec.europa.eu/eurostat/ data/database

Eurostat. (2020f). Population. Retrieved on 22.11.2020 from: https://ec.europa.eu/eurostat/data/database

Eurostat. (2020g). R\&D expenditures. Retrieved on 22.11.2020 from: https://ec.europa.eu/eurostat/ data/database

Eurostat. (2020i). Unemployed persons. Retrieved on 21.11.2020 from: https://ec.europa.eu/eurostat/ data/database

Eurostat. (2020j). Wages and salaries. Retrieved on 21.11.2020 from: https://ec.europa.eu/eurostat/ data/database

Eurostat. (2021a). Impact of Covid-19 crisis on non-financial corporation and household accounts. Retrieved on 19.01.2021 from https:// ec.europa.eu/eurostat/statistics-explained/index.php?title=Impact_of_Covid-19_crisis_on_ non-financial_corporation_and_household_ accounts\#Impact_of_COVID-19_lockdown_on_ the_collection.2C_compilation_and_dissemination_of_quarterly_sector_accounts_data

Eurostat. (2021b). Newsrelease euroindicators, 10. Eurostat press office. https://ec.europa.eu/eurostat/ documents/2995521/11562895/6-15012021 AP-EN.pdf/30bd5d3d-3ae6-d4c4-66ab$5142493 \mathrm{e} 9571$

Eurostat. (2021c). Newsrelease euroindicators, 8. Eurostat press office. https://ec.europa.eu/eurostat/ documents/2995521/11562887/4-13012021-APEN.pdf/6ee4a64a-ce47-c3d4-bbc9-a95c414e7b7c

Eurostat \& European Commission. (2008). NACE Rev. 2 Statistical classification of economic activities in the European Community. Office for Official Publications of the European Communities. https://ec.europa.eu/ eurostat/documents/3859598/5902521/KS-RA07-015-EN.PDF.pdf/dd5443f5-b886-40e4-920d9df03590ff91? $\mathrm{t}=1414781457000$

Fremstad, A., Petach, L., \& Tavani, D. (2019). Climate change, innovation, and economic growth: the contributions of William Nordhaus and Paul Romer. Review of Political Economy, 31(3), 336355. https://doi.org/10.1080/09538259.2019.166 3635

Fukao, K., \& Makino, T. (2021). Human capital and economic growth in Japan: 1885-2015. Journal of Economic Surveys, 35(3), 710-740. https://doi. org/10.1111/joes. 12419

Galor, O., \& Weil, D. N. (2000). Population, technology, and growth: From Malthusian stagnation to the demographic transition and beyond. American Economic Review, 90(4), 806-828. http://www. jstor.org/stable/117309

Gans, J. S. (2020). Economics in the age of COVID-19. The MIT Press.

Herrington, G. (2021). Update to limits to growth. Journal of Industrial Ecology, 25(3), 614-626. https://doi.org/10.1111/jiec.13084

Higgins, K. L. (2015). Economic growth and sustainability: Systems thinking for a complex world. Elsevier.

Hofman, A. A., \& Valderrama, P. (2021). Long run economic growth performance in Latin America - 1820-2016. Journal of Economic Surveys, 35(3), 833-869. https://doi.org/10.1111/joes. 12383

International Labour Organization. (2020). Almost 25 million jobs could be lost worldwide as a result of covid-19, says ILO: COVID-19: Protecting workers in the workplace [Press release, March 18]. https://www.ilo.org/global/about-the-ilo/newsroom/news/WCMS_738742/lang--en/index.htm

International Labour Organization. (2021). Labour force participation rate. Retrieved on 13.07.2021 from: https://www.ilo.org/ilostat-files/Documents/description_LFPR_EN.pdf

International Monetary Fund. (2020). World economic outlook: The great lockdown (April). International Monetary Fund. https://www.imf.org/en/Publications/WEO/Issues/2020/04/14/World-EconomicOutlook-April-2020-The-Great-Lockdown-49306 Jacob, M., Lamb, W. F., Steckel, J. C., Flachsland, C., \& Edenhofer, O. (2020). Understanding different perspectives on economic growth and climate policy. WIREs Climate Change, 11(6), e677. https:// doi.org/10.1002/wcc.677

Jones, C. I. (1995). R\&D-based models of economic growth. Journal of Political Economy, 103(4), 759784. http://www.jstor.org/stable/2138581

Khan, A., Khan, N., \& Shafiq, M. (2021). The economic impact of COVID-19 from a global perspective. Contemporary Economics, 15(1), 64-75. https:// doi.org/10.5709/ce.1897-9254.436

Kitamura, Y., Karkour, S., Ichisugi, Y., \& Itsubo, N. (2020). Evaluation of the economic, environmental, and social impacts of the COVID-19 pandemic on the Japanese tourism industry. Sustainability, 12(24), 10302. https://doi.org/10.3390/ su122410302

Maliszewska, M., Mattoo, A., \& van der Mensbrugghe, D. (2020). The potential impact of COVID -19 on GDP and trade: A preliminary assessment [Policy Research Working Paper 9211]. World Bank. 
Mankiw, N. G. (2019). Macroeconomics (10th ed.). Macmillan Learning.

Mankiw, N. G., Romer, D., \& Weil, D. N. (1992). A contribution to the empirics of economic growth. Quarterly journal of economics, 107(2), 407-437.

McKibbin, W., \& Fernando, R. (2020a). The economic impact of COVID-19. In R. Baldwin, \& B. Weder di Mauro (Eds.), Economics in the time of $\mathrm{COV}$ ID-19 (pp. 45-51). CEPR Press.

McKibbin, W., \& Fernando, R. (2020b). The global macroeconomic impacts of COVID-19: seven scenarios. CAMA working paper, 19, 1-43. The Australian national university. https://cama.crawford. anu.edu.au/sites/default/files/publication/cama_ crawford_anu_edu_au/2020-03/19_2020_mckibbin_fernando_0.pdf

Meadows, D. H., Randers, J., \& Meadows, D. L. (2005). Limits to growth: The 30-year update. Bath Press.

Meninno, R., \& Wolff, G. (2020). As coronavirus spreads, can the EU afford to close its borders? In R. Baldwin, \& B. Weder di Mauro (Eds.), Economics in the time of COVID-19 (pp. 87-91). CEPR Press.

Nordhaus, W. (2019). Climate change: The ultimate challenge for economics. American Economic Review, 109(6), 1991-2014. https://doi.org/10.1257/ aer.109.6.1991

OECD. (2020). Economic outlook, 2020(2). https:// doi.org/10.1787/39a88ab1-en

Ogbeifun, L., \& Shobande, O. A. (2021). A reevaluation of human capital accumulation and economic growth in OECD. Journal of Public Affairs, e02602. https://doi.org/10.1002/pa.2602

Romer, P. M. (1994). The origins of endogenous growth. Journal of economic perspectives, 8(1), 3-22.

Schwab, K., \& Malleret, T. (2020). COVID-19: The great reset. Cologny/Geneva: World economic forum.

Silva, G., \& Di Serio, L. C. (2016). The sixth wave of innovation: are we ready? RAI Revista de Administração e Inovação, 13(2), 128-134. https://doi. org/10.1016/j.rai.2016.03.005

Solow, R. M. (1956). A contribution to the theory of economic growth. Quarterly Journal of Economics, 70(1), 65-94. https://doi.org/10.2307/1884513

Spash, C. L. (2020). 'The economy' as if people mattered: revisiting critiques of economic growth in a time of crisis. Globalizations, 1-18. https://doi.org/ 10.1080/14747731.2020.1761612

Teixeira, A. A. C., \& Queirós, A. S. S. (2016). Economic growth, human capital and structural change: A dynamic panel data analysis. Research Policy,
45(8), 1636-1648. https://doi.org/10.1016/j.respol.2016.04.006

United Nation. (2020). Sustainable development outlook 2020. Achieving SDGs in the wake of COVID-19: scenarios for policymakers. United Nations, Department of Economic and Social Affairs. https://www.un.org/development/desa/ dpad/wp-content/uploads/sites/45/publication/ SDO2020_Book.pdf

World Bank. (2020). Global economic prospects (June). World Bank. http://dx.doi.org/10.1596/978-14648-1553-9

World Trade Organization. (2020). Methodology for the WTO trade forecast (April). World Trade Organization.

Wren-Lewis, S. (2020). The economic effects of a pandemic. In R. Baldwin, \& B. Weder di Mauro (Eds.), Economics in the time of COVID-19 (pp. 109-112). CEPR Press. 